\title{
Synthesis of cationic star polymers by simplified electrochemically mediated ATRP
}

\section{P. Chmielarz*}

Department of Physical Chemistry, Faculty of Chemistry, Rzeszów University of Technology, Al. Powstańców Warszawy 6, 35-959 Rzeszów, Poland

Received 23 March 2016; accepted in revised form 16 May 2016

\begin{abstract}
Cyclodextrin-based cationic star polymers were synthesized using $\beta$-cyclodextrin ( $\beta$-CD) core, and 2-(dimethylamino)ethyl methacrylate (DMAEMA) as hydrophilic arms. Star-shaped polymers were prepared via a simplified electrochemically mediated ATRP (seATRP) under potentiostatic and galvanostatic conditions. The polymerization results showed molecular weight (MW) evolution close to theoretical values, and maintained narrow molecular weight distribution (MWD) of obtained stars. The rate of the polymerizations was controlled by applying more positive potential values thereby suppressing star-star coupling reactions. Successful chain extension of the $\omega$-functional arms with a hydrophobic $n$-butyl acrylate (BA) formed star block copolymers and confirmed the living nature of the $\beta$-CD-PDMAEMA star polymers prepared by seATRP. Novelty of this work is that the $\beta$-CD-PDMAEMA- $b$-PBA cationic star block copolymers were synthesized for the first time via seATRP procedure, utilizing only $40 \mathrm{ppm}$ of catalyst complex. The results from ${ }^{1} \mathrm{H}$ NMR spectral studies support the formation of cationic star (co)polymers.
\end{abstract}

Keywords: polymer synthesis, seATRP, amphiphilic star copolymers

\section{Introduction}

Atom transfer radical polymerization (ATRP) is proven to be one of the most versatile reversible deactivation radical polymerization (RDRP) methods that enables the preparation of polymers with controlled molecular weights (MWs), narrow molecular weight distributions $\left(M_{\mathrm{w}} / M_{\mathrm{n}}, \mathrm{MWDs}\right)$, and targeted degrees of polymerization (DP) [1-13]. The advent of low amount catalyst ATRP system, such as simplified electrochemically mediated ATRP (seATRP) [14] offers more environmentally friendly reaction conditions for the synthesis of polymers [15]. In seATRP a desired amount of the catalyst complex $\left(\mathrm{X}-\mathrm{Cu}^{\mathrm{II}} / \mathrm{L}\right)$ can be electrochemically reduced to $\left(\mathrm{Cu}^{\mathrm{I}} / \mathrm{L}\right)$ activators to start a controlled polymerization [16]. The reduced activator then spreads out into reaction mixture by vigorous stirring, and reacts with initiators $(\mathrm{P}-\mathrm{X})$ to form radical species $\left(\mathrm{P}^{*}\right)$ and is oxidized back to $\left(\mathrm{X}-\mathrm{Cu}{ }^{\mathrm{II}} / \mathrm{L}\right)$. Consequently, the radical species propagate to form polymeric chains by reacting with monomers $(\mathrm{M})$, or are deactivated back to the dormant species $\left(\mathrm{P}_{\mathrm{n}}-\mathrm{X}\right)$ (Figure 1) [14, 15, 17, 18].

This method has been applied to hydrophobic (meth) acrylates [14, 15, 19-26], and hydrophilic (meth)acrylates and (meth)acrylamides [14, 16-18, 25, 27-31] for the synthesis of well-defined polymeric architec-

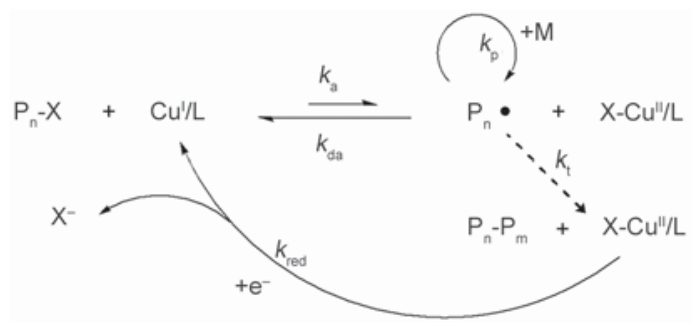

Figure 1. Mechanism of seATRP [19]

${ }^{*}$ Corresponding author, e-mail: : p_chmiel@prz.edu.pl (C) BME-PT 
tures. Star-shaped cationic polymers, consisting of multiple arms linked to a central $\beta$-cyclodextrin $(\beta$ $\mathrm{CD})$ core, have recently attracted much attention, because of their dense branched architecture with moderate flexibility, tunable properties like solubility, chemically crosslinked structure, temperature or $\mathrm{pH}$ sensitivity, which could be manipulated by the parameters such as the block composition, MW, and arm number [32-44].

Amphiphilic star copolymers composed of poly(2dimethylaminoethyl methacrylate)-block-poly(n-butyl acrylate) (PDMAEMA- $b$-PBA) arms covalently linked to a $\beta-C D$ core are especially interesting, because they can be used in biomedical applications, including drug delivery and tissue engineering. PDMAEMA is the most extensively studied $\mathrm{pH}$-responsive polymer [45-50], because it is able to function as the $\mathrm{pH}$-responsive component as it has a nitrogen moiety, which can be protonated by lowering the $\mathrm{pH}$ of the solution $[48,49]$, and shows $\mathrm{pH}$-dependent lower critical solution temperature behavior [45] and upper critical solution temperature behavior at low temperatures in the presence of multivalent counter ions [47]. Furthermore PBA is an industrially important polymer because of its low glass-transition temperature, durability, and potential use as a soft segment in thermoplastic elastomers [51, 52].

The main objective of this article is to report the first example of the preparation of well-defined star-shaped cationic polymers, consisting of the $\beta-\mathrm{CD}$ core and the respective PDMAEMA and PDMAEMA- $b$-PBA arms by seATRP, under both potentiostatic and galvanostatic conditions. In this case, the arm of the star polymer is composed of a cationic PDMAEMA block and a hydrophobic PBA block. It was presented that polymerization conditions were optimized (including the effect of applied potential on the polymerization behavior) to provide fast reactions while employing low catalyst concentrations and preparation of star copolymers with narrow MWDs. Therefore, well-defined cationic block star copolymers, with a $\beta$-CD core were successfully produced through appropriate selection of experimental conditions.

\section{Experimental section}

\subsection{Materials}

$\beta$-Cyclodextrin ( $\beta$-CD, $M_{\mathrm{n}}=1,135$ ), 2-bromoisobutyryl bromide (BriBBr, 98\%), $N$-methyl-2-pyrroli- done (NMP, >99\%), dichloromethane (DCM, $>99.5 \%), n$-hexane (95\%), sodium bicarbonate $(>99.7 \%$ ), tetrabutylammonium perchlorate (TBAP, $>98 \%$ ), copper(II) bromide ( $\left.\mathrm{Cu}^{\mathrm{II}} \mathrm{Br}_{2}, 99.999 \%\right)$, and methylated cellulose (Tylose, $\mathrm{MH}=300$ ) were purchased from Aldrich, USA. $N, N$-Dimethylformamide (DMF, 99.9\%) was purchased from Acros, Belgium. These reagents were used without further purification. Tris(2-pyridylmethyl)amine (TPMA) was prepared according to a published procedure [53]. Stock solutions of $\mathrm{Cu}^{\mathrm{II}} \mathrm{Br}_{2}$ and TPMA were prepared according to a previously described in reference [18]. The $\beta$-CD-Br ${ }_{21}$ ATRP initiator was prepared by reacting $\beta$-CD with BriBBr in NMP according to procedure described in reference [54] and characterized according to our previous work [15]. 2-(Dimethylamino)ethyl methacrylate (DMAEMA; 98\%; SigmaAldrich, USA) and $n$-butyl acrylate (BA; $>99 \%$; Sigma-Aldrich, USA) were passed through a column filled with basic alumina prior to use to remove any inhibitor. Platinum (Pt) wire, $\mathrm{Pt}$ gauge mesh and $\mathrm{Pt}$ disk (3 mm diameter, Gamry) were purchased from Alfa Aesar, USA. All cyclic voltammetry (CVs) and preparative electrolysis were conducted in electrochemical cell kit (Gamry, USA).

\subsection{Analysis}

${ }^{1} \mathrm{H}$ NMR spectra in $\mathrm{CDCl}_{3}$ were measured using Bruker Avance $500 \mathrm{MHz}$ spectrometer. Monomer conversion and theoretical number-average molecular weight $\left(M_{\mathrm{n}, \mathrm{th}}\right)$ were determined by NMR based on the previous research [17]. MWs and MWDs were determined by GPC (Polymer Standards Services (PSS) columns (guard, $10^{5}, 10^{3}$, and $10^{2} \AA$ ), with THF eluent, flow rate $1.00 \mathrm{~mL} / \mathrm{min}$, and with a differential refractive index (RI) detector (Viscotek, T60A)). The apparent molecular weights (MWs) and dispersity $\left(M_{\mathrm{w}} / M_{\mathrm{n}}\right)$ were determined with a calibration based on PS standards using TRISEC software. CVs and preparative electrolysis were recorded on a Metrohm Autolab potentiostat (AUT84337) using GPES software from EcoChemie B. V. Corporation. The electrolysis were carried out under Ar atmosphere using a Pt disk for $\mathrm{CV},\left(A=0.071 \mathrm{~cm}^{2}\right)$ and Pt mesh for preparative electrolysis, $\left(A=\sim 6 \mathrm{~cm}^{2}\right)$ working electrodes (WE). The counter electrode (CE, sacrificial anode) was Al wire ( $l=10 \mathrm{~cm}, d=1 \mathrm{~mm})$. Values for potentials applied for preparative electrolysis were 
established from $\mathrm{CV}$ measurements at a $100 \mathrm{mV} / \mathrm{s}$ scan rate using saturated calomel electrode (SCE; Gamry) reference electrode (RE) according to the previous research [15].

\subsection{Synthesis of $\beta$-CD-(PDMAEMA $)_{21}$ star polymers by seATRP}

The synthesis of $\beta$-CD-(PDMAEMA) 21 star polymers was conducted under potentiostatic and galvanostatic conditions (Figure 2).

$\operatorname{TBAP}(1.64 \mathrm{~g}, 5 \mathrm{mmol})$ was placed in an electrolysis cell maintained at $50^{\circ} \mathrm{C}$ under an Ar purge. Then, $12 \mathrm{~mL}$ of Ar purged DMAEMA (71 mmol), DMF $(8.9 \mathrm{~mL})$ and $57 \mu \mathrm{L}$ of $\mathrm{Cu}^{\mathrm{II}} \mathrm{Br}_{2} / 2$ TPMA stock solution $(0.05 \mathrm{M}$ in DMF) were added to the reaction cell. The CV was recorded using a Pt disk WE, a SCE RE, and an $\mathrm{Al}$ wire $\mathrm{CE}$ for determining the appropriate applied potential $\left(E_{\mathrm{app}}=E_{\mathrm{pc}}, E_{\mathrm{app}}=E_{\mathrm{pc}}-30 \mathrm{mV}\right.$, $E_{\text {app }}=E_{\mathrm{pc}}-60 \mathrm{mV}$, and $\left.E_{\text {app }}=E_{\mathrm{pc}}-100 \mathrm{mV}\right)$. A solution of $451 \mathrm{mg}$ of $\beta-\mathrm{CD}-\mathrm{Br}_{21}(0.11 \mathrm{mmol})$ in $3 \mathrm{~mL}$ of $\mathrm{DMF}$ was injected to the reaction solution and the $\mathrm{CV}$ was measured to confirm an increased cathodic response. Then the Pt mesh WE, Al wire CE, and SCE $\mathrm{RE}$ were prepared and immersed in the polymerization solution and the selected potential was applied using the preparative electrolysis method.

After the initial seATRP polymerization under potentiostatic conditions the proper applied current values were calculated based on $I=Q / \mathrm{s}$ for each step. An identical reaction mixture was prepared and the polymerization was carried out under multiple applied currents $\left(I_{\mathrm{app}, 1}=(-) 0.52 \mathrm{~mA} \quad(0.33 \mathrm{~h}), \quad I_{\mathrm{app}, 2}=\right.$ $(-) 0.30 \mathrm{~mA}(0.33 \mathrm{~h}), I_{\mathrm{app}, 3}=(-) 0.19 \mathrm{~mA}(0.56 \mathrm{~h})$, $I_{\text {app }, 4}=(-) 0.09 \mathrm{~mA}(0.56 \mathrm{~h}), I_{\mathrm{app}, 5}=(-) 0.04 \mathrm{~mA}$
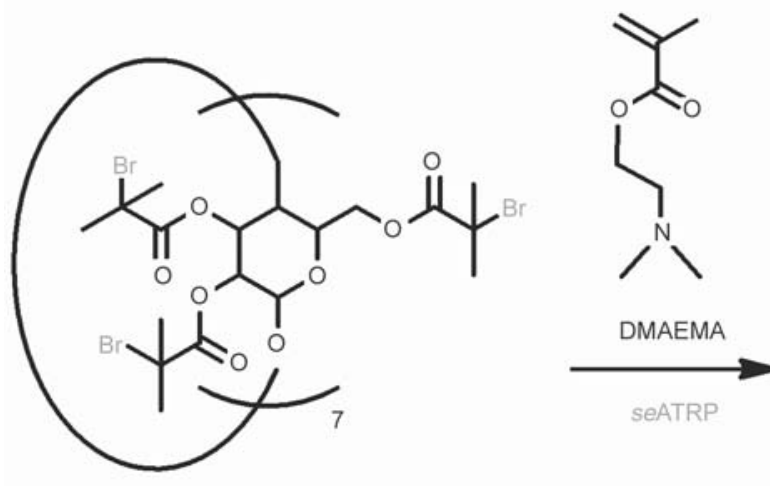

$\beta-\mathrm{CD}-\mathrm{Br}_{21}$
$(1.22 \mathrm{~h}))$. In both cases samples were withdrawn periodically to follow the monomer conversion, using ${ }^{1} \mathrm{H}$ NMR. The $M_{\mathrm{n}}$ and $M_{\mathrm{w}} / M_{\mathrm{n}}$ were determined by GPC measurements (with PS standard curve). The product was purified by dialysis against water (Spectra/Por dialysis membrane, MWCO 1000, Spectrum Laboratories Inc.), dried by air, dissolved in acetone, passed through a neutral alumina column in order to remove catalyst, and dried under vacuum for 5 days. The polymer was then isolated and characterized using ${ }^{1} \mathrm{H}$ NMR.

\subsection{Chain extension of a $\beta$-CD-(PDMAEMA) $)_{21}$ star macroinitiator with $\mathrm{BA}$}

The synthesis of $\beta$-CD-(PDMAEMA- $b$-PBA) $)_{21}$ star block copolymers was conducted under potentiostatic and galvanostatic conditions (Figure 3).

The seATRP method was also used for the chain extension of the $\beta$-CD-(PDMAEMA-Br) $)_{21}$ macroinitiator with BA. Polymerization conditions: $[\mathrm{BA}]_{0} /[\beta-$ CD-(PDMAEMA-Br $\left.)_{21}\right]_{0} /\left[\mathrm{Cu}^{\mathrm{II}} \mathrm{Br}_{2} / 2 \mathrm{TPMA}\right]_{0}=$ $32 / 1 / 0.0013,[\mathrm{BA}]_{0}=2.1 \mathrm{M}$ in DMF, $\left[\mathrm{Cu}^{\mathrm{II}} \mathrm{Br}_{2} /\right.$ $2 \mathrm{TPMA}]_{0}=0.08 \mathrm{mM},[\mathrm{TBAP}]_{0}=0.2 \mathrm{M}, E_{\text {app }}=$ $E_{\mathrm{pc}}-60 \mathrm{mV}$ (vs. $\mathrm{SCE}$ ), $T=50^{\circ} \mathrm{C}, \mathrm{WE}=$ Pt mesh, $\mathrm{CE}=$ $\mathrm{Al}$ wire, and $\mathrm{RE}=\mathrm{SCE}$. An identical reaction mixture was prepared and seATRP was carried out under multiple applied currents $\left(I_{\text {app }, 1}=(-) 0.38 \mathrm{~mA}(0.67 \mathrm{~h})\right.$, $I_{\text {app }, 2}=(-) 0.15 \mathrm{~mA}(0.67 \mathrm{~h}), I_{\mathrm{app}, 3}=(-) 0.04 \mathrm{~mA}$ $\left.(0.67 \mathrm{~h}), I_{\text {app }, 4}=(-) 0.01 \mathrm{~mA}(1.0 \mathrm{~h})\right)$. In both cases samples were withdrawn periodically to follow the monomer conversion, using ${ }^{1} \mathrm{H}$ NMR. The $M_{\mathrm{n}}$ and $M_{\mathrm{w}} / M_{\mathrm{n}}$ were determined by GPC measurements (with PS standard curve). The product was purified by dialysis against water and methanol (MWCO 1000), and

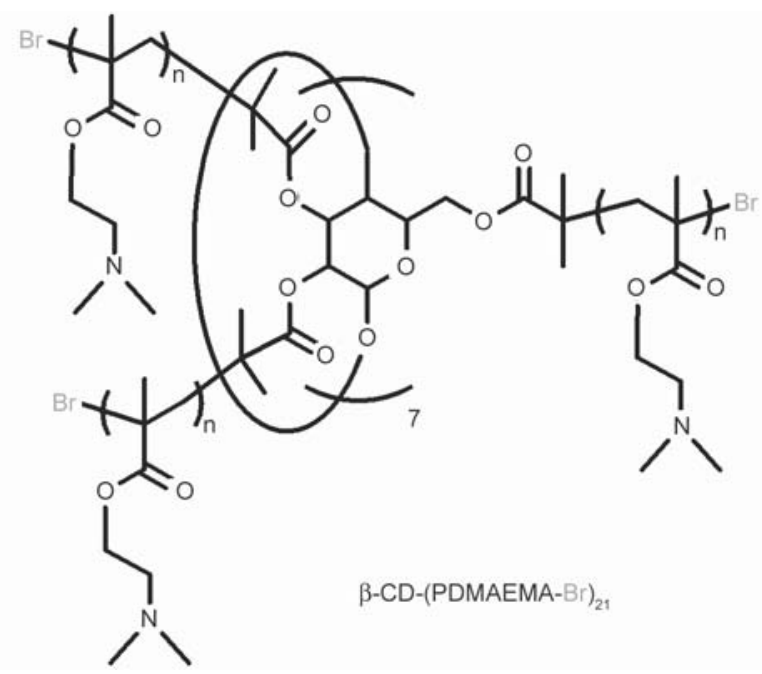

Figure 2. Synthesis of $\beta$-CD-(PDMAEMA) ${ }_{21}$ star polymers via seATRP 


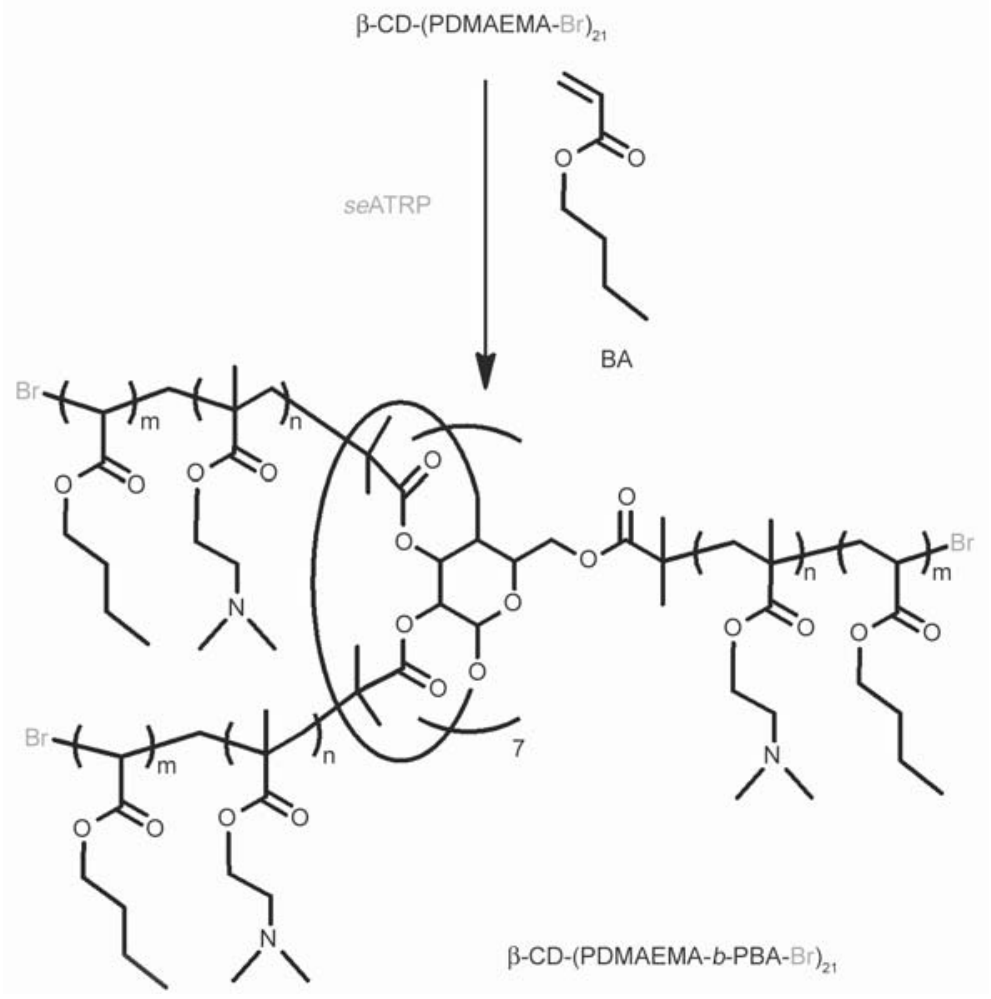

Figure 3. Synthesis of $\beta$-CD-(PDMAEMA- $b$-PBA) ${ }_{21}$ star block copolymers via seATRP

dried under vacuum for 5 days. The polymer was then isolated and characterized using ${ }^{1} \mathrm{H}$ NMR.

\section{Results and discussion}

Well-controlled ATRP synthesis of star polymers is challenging when chain extension occurs from a macroinitiator of lower activity to a more active monomer [24]. The rate of activation of a bromo-terminated PDMAEMA chain end is faster than the ac- tivation of a 2-bromoisobutyrate $\beta$-CD chain ends ( $\omega$-functional arms) $[55,56]$. Typically, halogen exchange procedures [55-58] are employed to solve this problem, but it can't be used for systems with low concentrations of catalyst, because of poor initiation efficiency.

Here we have demonstrated new proposition of solving the problem with poor initiation efficiency by seATRP procedure. In this paper synthesis of cation-

Table 1. Summary of cationic star polymers synthesis by seATRP

\begin{tabular}{|c|c|c|c|c|c|c|c|c|}
\hline Entry & {$[\mathrm{M}]_{0} /[\mathrm{I}]_{0} /\left[\mathrm{Cu}^{\mathrm{II}} \mathrm{Br}_{2} / 2 \mathrm{TPMA}\right]_{0}$} & $E_{\text {app }}{ }^{(a)}$ & $\begin{array}{c}k_{\mathrm{p}}^{\text {app(b) }} \\
{\left[\mathrm{h}^{-1}\right]}\end{array}$ & $\begin{array}{c}\text { Conv }^{(\mathbf{b})} \\
{[\%]}\end{array}$ & $\mathrm{DP}_{\text {app }}{ }^{(\mathrm{b})}$ (per arm) & $M_{\mathrm{n}, \text { theo }}{ }^{(\mathrm{c})}\left(\cdot 10^{-3}\right)$ & $M_{\mathrm{n}}^{\text {app(d) }}\left(\cdot 10^{-3}\right)$ & $M_{\mathrm{w}} / M_{\mathrm{n}}{ }^{(\mathrm{d})}$ \\
\hline 1 & $32 / 1 / 0.0013$ & $E_{\mathrm{pc}}$ & 0.202 & 45 & 14 & 51.5 & 45.0 & 1.08 \\
\hline 2 & $32 / 1 / 0.0013$ & $E_{\mathrm{pc}}-30 \mathrm{mV}$ & 0.417 & 70 & 23 & 78.7 & 67.7 & 1.09 \\
\hline 3 & $32 / 1 / 0.0013$ & $E_{\mathrm{pc}}-60 \mathrm{mV}$ & 0.772 & 90 & 29 & 99.3 & 80.7 & 1.09 \\
\hline 4 & $32 / 1 / 0.0013$ & $E_{\mathrm{pc}}-100 \mathrm{mV}$ & 0.947 & 94 & 30 & 103.9 & 135.0 & 1.63 \\
\hline 5 & $32 / 1 / 0.0013$ & $\begin{array}{l}\text { Galvanostatic } \\
\text { conditions }^{(\mathrm{e})}\end{array}$ & 0.709 & 88 & 28 & 97.1 & 78.5 & 1.08 \\
\hline 6 & $32 / 1 / 0.0013$ & $E_{\mathrm{pc}}-60 \mathrm{mV}$ & 0.577 & 82 & 26 & 167.7 & 135.6 & 1.15 \\
\hline 7 & $32 / 1 / 0.0013$ & $\begin{array}{l}\text { Galvanostatic } \\
\text { conditions }^{(\mathrm{f})}\end{array}$ & 0.523 & 79 & 25 & 165.1 & 132.0 & 1.14 \\
\hline
\end{tabular}

General reaction conditions: $T=50^{\circ} \mathrm{C} ; V_{\text {tot }}=24 \mathrm{~mL}$ (except entry 6 and $\left.7: V_{\text {tot }}=16 \mathrm{~mL}\right) ; t=3 \mathrm{~h} ;[\mathrm{M}]_{0}:[\mathrm{DMAEMA}]_{0}=3.0 \mathrm{M}($ except entry 6 and 7: $\left.[\mathrm{BA}]_{0}=2.1 \mathrm{M}\right) ;[\mathrm{I}]_{0}:\left[\beta-\mathrm{CD}-\mathrm{Br}_{21}\right]_{0}=4.4 \mathrm{mM}$ calculated per $21 \mathrm{Br}$ (except entry 6 and 7: $\left[\beta-\mathrm{CD}-(\mathrm{PDMAEMA}-\mathrm{Br})_{21}\right]_{0}=$ $3.1 \mathrm{mM}$ calculated per $21 \mathrm{Br}) ;\left[\mathrm{Cu}^{\mathrm{II}} \mathrm{Br}_{2} / 2 \mathrm{TPMA}\right]_{0}=0.12 \mathrm{mM}$ except entry 6 and $\left.7:=0.08 \mathrm{mM}\right)$; $[\mathrm{TBAP}]_{0}=0.2 \mathrm{M}$. seATRP under potentiostatic conditions $(\mathrm{WE}=\mathrm{Pt}$ mesh, $\mathrm{CE}=\mathrm{Al}$ wire $(l=10 \mathrm{~cm}, d=1 \mathrm{~mm}), \mathrm{RE}=\mathrm{SCE})$ : entries $1-4$ and 6 ; seATRP under galvanostatic conditions (WE and CE without RE): entry 5 and 7.

${ }^{\mathrm{a}} E_{\text {app }}$ were selected based on $\mathrm{CV}$ analysis $(v=100 \mathrm{mV} / \mathrm{s}) ;{ }^{\mathrm{b}}$ Monomer conversion, apparent propagation constants $\left(k_{\mathrm{p}}^{\text {app }}\right)$, and apparent practical degree of polymerization of monomer unit per arm $\left(\mathrm{DP}_{\text {app }}\right)$ were determined by NMR; ${ }^{\mathrm{c}} M_{\mathrm{n} \text {,theo }}=\left([\mathrm{M}]_{0} /[\mathrm{MI}]_{0}\right) \times$ conversion $\times M_{\text {monomer }}$ $+M_{\text {initiator }}$; ${ }^{\mathrm{d}}$ apparent $M_{\mathrm{n}}$ and MWD were determined by THF GPC with PS standard; ${ }^{\mathrm{e}} I_{\text {app }}=-0.52,-0.30,-0.19,-0.09$, and $-0.04 \mathrm{~mA}$ for each steps; ${ }^{\mathrm{f}} I_{\text {app }}=-0.51,-0.22,-0.11,-0.05$, and $-0.03 \mathrm{~mA}$ for each steps. 
ic star copolymers by seATRP are reported for the first time using only $40 \mathrm{ppm}$ of $\mathrm{Cu}^{\mathrm{II}} / \mathrm{L}$ in solution. Table 1 summarizes the results of the star polymers synthesis using the $\beta$-CD based macroinitiator $\left(M_{\mathrm{n}}=\right.$ $\left.4260, M_{\mathrm{w}} / M_{\mathrm{n}}=1.06\right)$ under both potentiostatic and galvanostatic conditions.

The structure of the ligand, monomer, dormant species as well as reaction conditions (solvent, temperature and pressure) can strongly influence the values of the rate constants $\left(k_{\mathrm{a}}, k_{\mathrm{da}}\right.$ and $\left.K_{\mathrm{ATRP}}\left(=k_{\mathrm{a}} / k_{\mathrm{da}}\right)\right)[5,19]$. In most cases electrochemically mediated ATRP reactions were carried out in DMF [14, 15, 19, 23, 24] and acetonitrile (MeCN) [20] as solvents. The polymerization in DMF was faster in comparison to the reactions conducted in $\mathrm{MeCN}$, this is because more polar system could enhance ATRP equilibrium constants $\left(K_{\mathrm{ATRP}}=k_{\mathrm{a}} / k_{\mathrm{da}}\right)$ [59]. For example, $K_{\text {ATRP value }}$ in aqueous condition is $c a .10^{3}$ times higher than
$\mathrm{MeCN}$ condition. In contrast, less polar solvent condition such as anisole mixture would require higher concentration of the supporting electrolyte to achieve better conductivity [60]. Moreover it is well known that temperature plays a vital role in controlled polymerization systems, because the activation rate constants increased with increasing temperature [61, $62]$. Thus, the objective of this study was to investigate and optimize polymerization conditions for seATRP of DMAEMA (in terms of $R_{\mathrm{p}}$, controlled MWs and narrow MWDs).

\subsection{Influence of different applied potential}

The effect of applied potential $\left(E_{\mathrm{app}}=E_{\mathrm{pc}}, E_{\mathrm{app}}=\right.$ $E_{\mathrm{pc}}-30 \mathrm{mV}, \quad E_{\mathrm{app}}=E_{\mathrm{pc}}-60 \mathrm{mV}$, and $E_{\mathrm{app}}=$ $E_{\mathrm{pc}}-100 \mathrm{mV}$ ) on the polymerization behavior was investigated as reported in Table 1 , entries $1-4$, and Figure 4. In essence, the fastest $k_{\mathrm{p}}^{\text {app }}$ (thereby $R_{\mathrm{p}}$ ) and

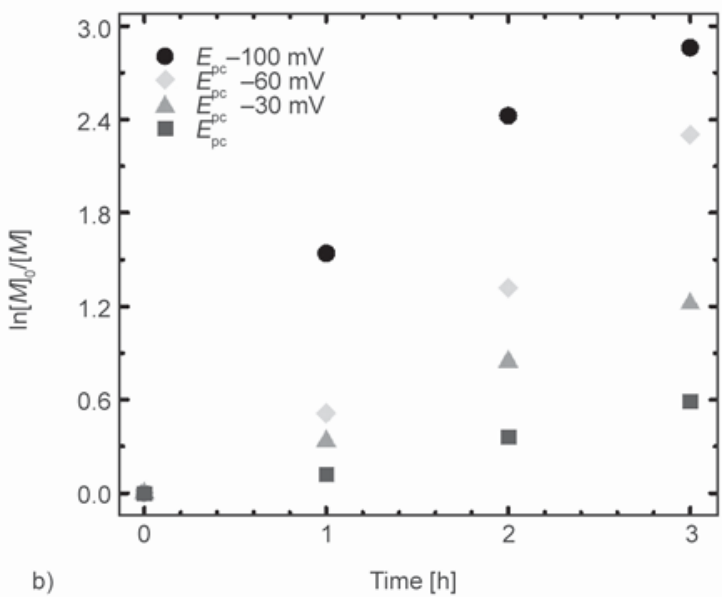

a)
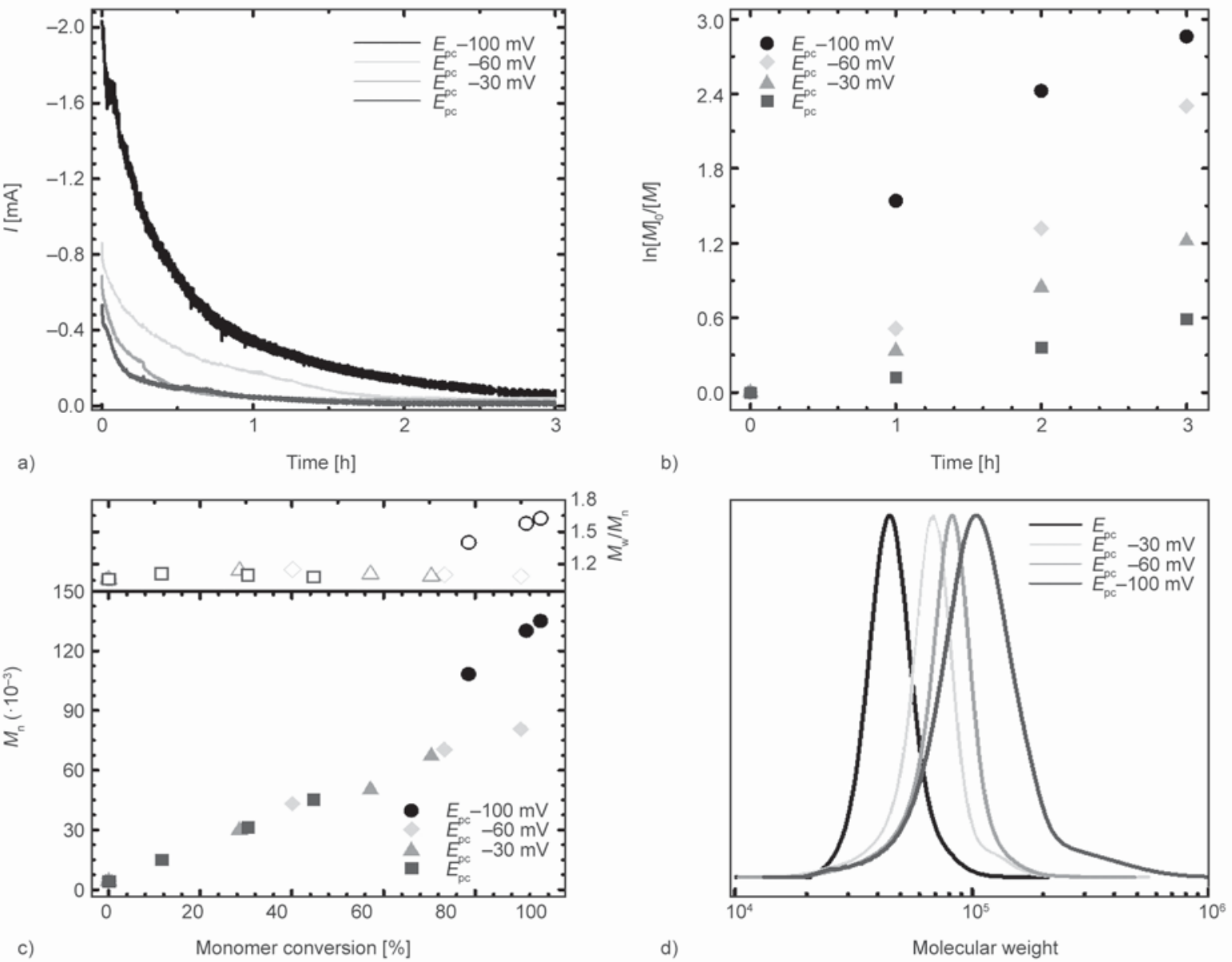

Figure 4. Synthesis of $\beta$-CD-PDMAEMA star-shaped polymers as a function of applied potential; (a) current profile versus time, (b) first-order kinetic plots, (c) $M_{\mathrm{n}}$ and $M_{\mathrm{w}} / M_{\mathrm{n}}$ versus monomer conversion, and (d) GPC results of DMAEMA polymerization for different $E_{\text {app }}$ values (final GPC traces for each reactions). Reaction conditions: [DMAEMA] $/$ $\left[\beta-\mathrm{CD}-\mathrm{Br}_{21}(\text { per }-\mathrm{Br})\right]_{0} /\left[\mathrm{Cu}^{\mathrm{II}} \mathrm{Br}_{2} / 2 \mathrm{TPMA}\right]_{0}=32 / 1 / 0.0013,[\mathrm{DMAEMA}]_{0}=3.0 \mathrm{M},\left[\mathrm{Cu}^{\mathrm{II}} \mathrm{Br}_{2} / 2 \mathrm{TPMA}\right]_{0}=0.12 \mathrm{mM}$, $T=50^{\circ} \mathrm{C},[\mathrm{TBAP}]_{0}=0.2 \mathrm{M}, V_{\mathrm{tot}}=24 \mathrm{~mL}, E_{\mathrm{app}}=E_{\mathrm{pc}}, E_{\mathrm{app}}=E_{\mathrm{pc}}-30 \mathrm{mV}, E_{\mathrm{app}}=E_{\mathrm{pc}}-60 \mathrm{mV}, E_{\mathrm{app}}=E_{\mathrm{pc}}-100 \mathrm{mV}$ (vs. SCE). 
larger cathodic currents (faster rate of reduction) were observed when more negative potential was applied (compare $k_{\mathrm{p}}$ app; Table 1 , entries 4 vs. $1-3$ ). In this case, faster rates of reduction provide a higher $\left[\mathrm{Cu}^{\mathrm{I}} / \mathrm{L}\right]$ and $\left[\mathrm{P}^{*}\right]$ leads to a higher $R_{\mathrm{p}}[19]$.

The polymerization results for more positive applied potentials $\left(E_{\mathrm{pc}}, E_{\mathrm{pc}}-30 \mathrm{mV}\right.$ and $E_{\mathrm{pc}}-60 \mathrm{mV}$ ) showed a linear increase of $M_{\mathrm{n}}$ with conversion (Figure 4c), and low $M_{\mathrm{w}} / M_{\mathrm{n}}$ values of obtained stars (Figure $4 \mathrm{c}-$ $4 d)$. On the other hand GPC trace of $\beta$-CD-PDMAEMA received at the most negative $E_{\text {app }}\left(E_{\mathrm{pc}}-100 \mathrm{mV}\right.$, Figure $4 \mathrm{~d}$ ) showed the presence of a significant high molecular weight shoulder attributed to a higher occurrence of star-star intermolecular X-linking reaction via a coupling process as well as intramolecular coupling, which lead to less uniform growth of arms [63].

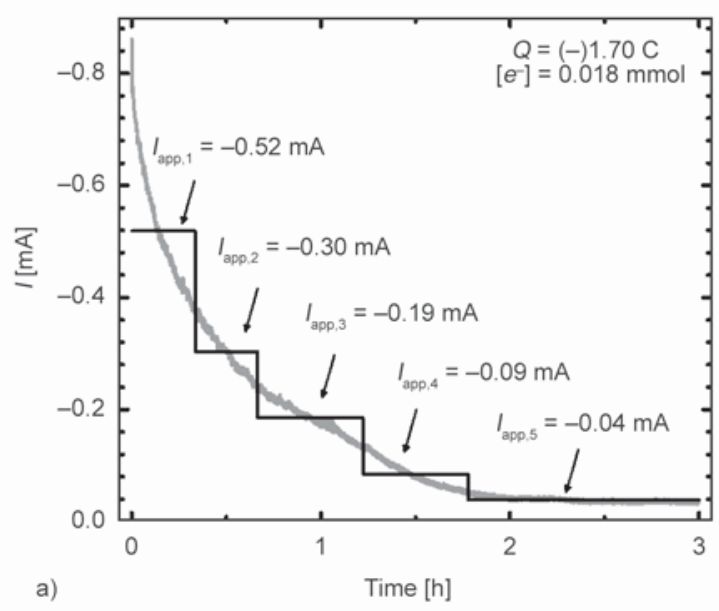

\subsection{Synthesis of 21-arm star block copolymers}

The preparation of CD star homopolymers with 21arms of PDMAEMA under potentiostatic and galvanostatic conditions were carried out and the results are reported in Table 1, entries 3 and 5, Figure 5 and 6. Nearly identical first-order kinetic plots were observed (Figure 5b), with linear MW evolution (Figure 5c), and GPC analysis indicated narrow MWD (Figure 5a, 6a and 6b).

Chain end functionality was evaluated by chain extension from $\beta$-CD-(PDMAEMA $\left.{ }_{28}\right)_{21}$ macroinitiator $\left(M_{\mathrm{n}}=97100, M_{\mathrm{w}} / M_{\mathrm{n}}=1.08\right.$; Table 1 , entry 5$)$ with $\mathrm{BA}$ as the second monomer to form a star block copolymers under both copolymers under potentiostatic and galvanostatic conditions (Table 1, entries 6-7, Figure 7 and 8).
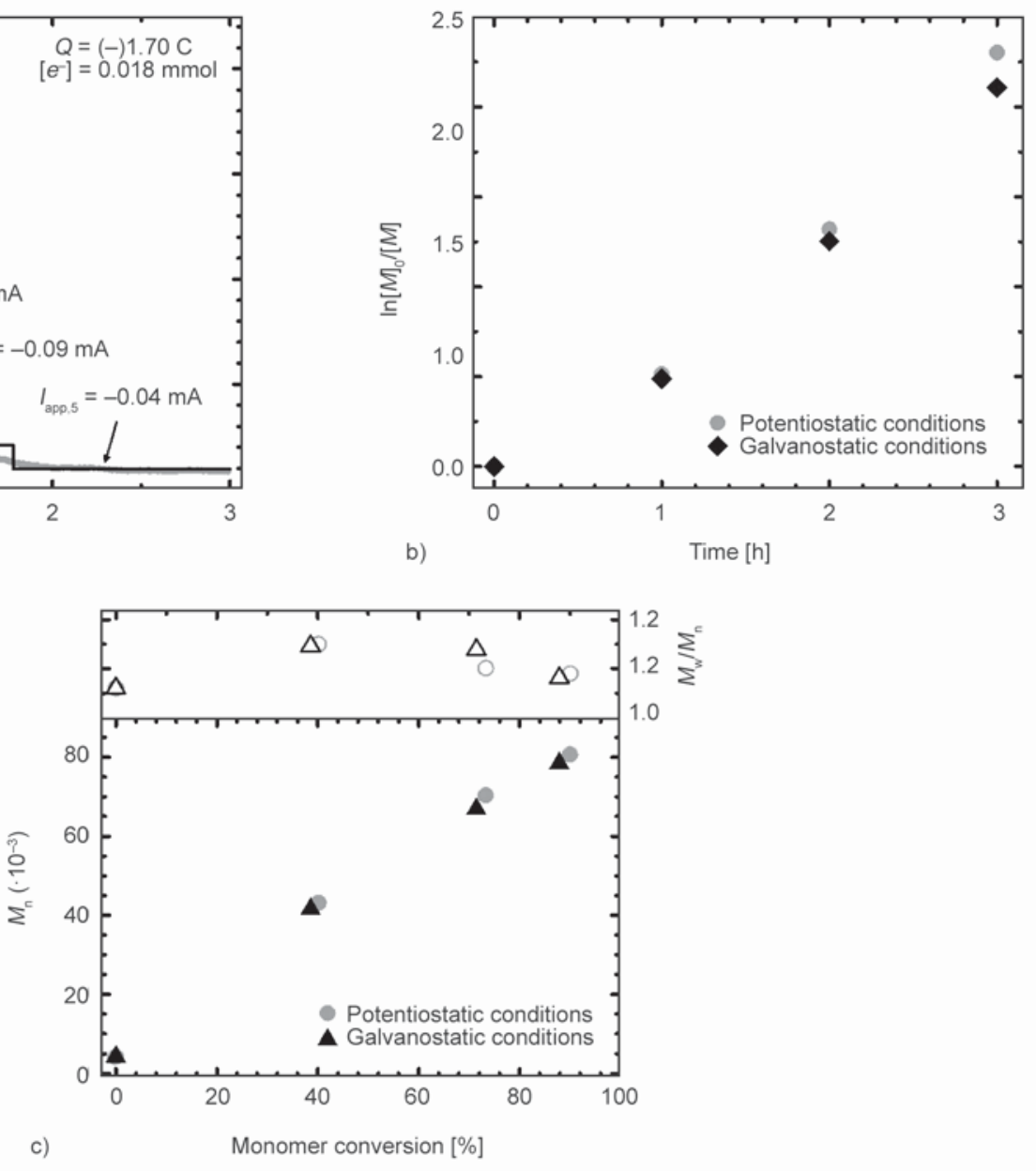

Figure 5. Multi-step preparative electrolysis for seATRP; (a) preparative electrolysis results from applied potential conditions (grey line) and applied current (black line), (b) first-order kinetic plot of monomer conversion versus time, and (c) $M_{\mathrm{n}}$ and $M_{\mathrm{w}} / M_{\mathrm{n}}$ versus monomer conversion by potentiostatic and galvanostatic conditions. Reaction conditions: $[\text { DMAEMA }]_{0} /\left[\beta-C D-B_{21}(\text { per }-\mathrm{Br})\right]_{0} /\left[\mathrm{Cu}^{\mathrm{II}} \mathrm{Br}_{2} / 2 \mathrm{TPMA}\right]_{0}=32 / 1 / 0.0013,[\mathrm{DMAEMA}]_{0}=3.0 \mathrm{M},\left[\mathrm{Cu}^{\mathrm{II}} \mathrm{Br}_{2} / 2 \mathrm{TPMA}\right]_{0}=$ $0.12 \mathrm{mM}, T=50^{\circ} \mathrm{C},[\mathrm{TBAP}]_{0}=0.2 \mathrm{M}, V_{\text {tot }}=24 \mathrm{~mL}$. 

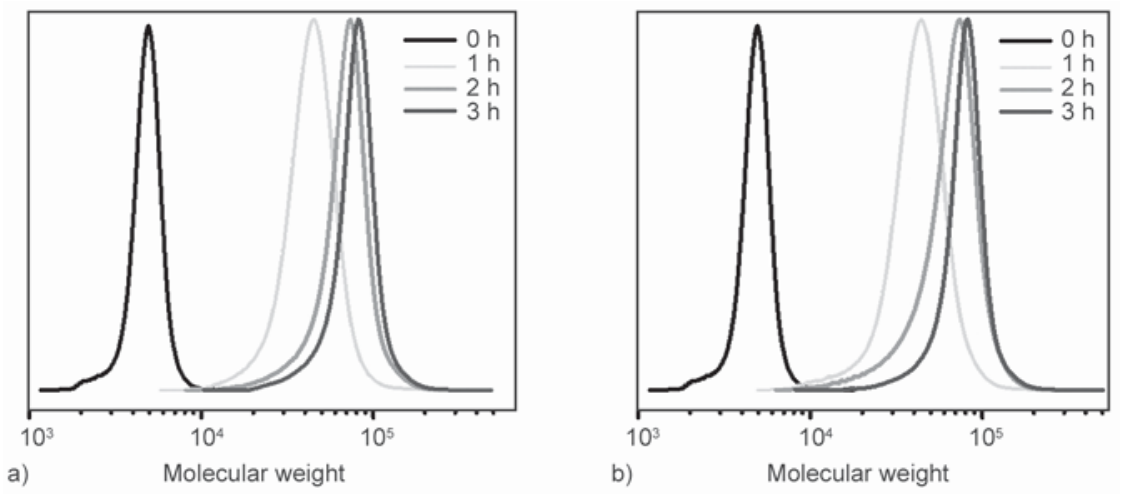

Figure 6. GPC traces of DMAEMA polymerization in the presence of $\beta-\mathrm{CD}-\mathrm{Br}_{21}$ under potentiostatic seATRP (a) and galvanostatic seATRP (b)
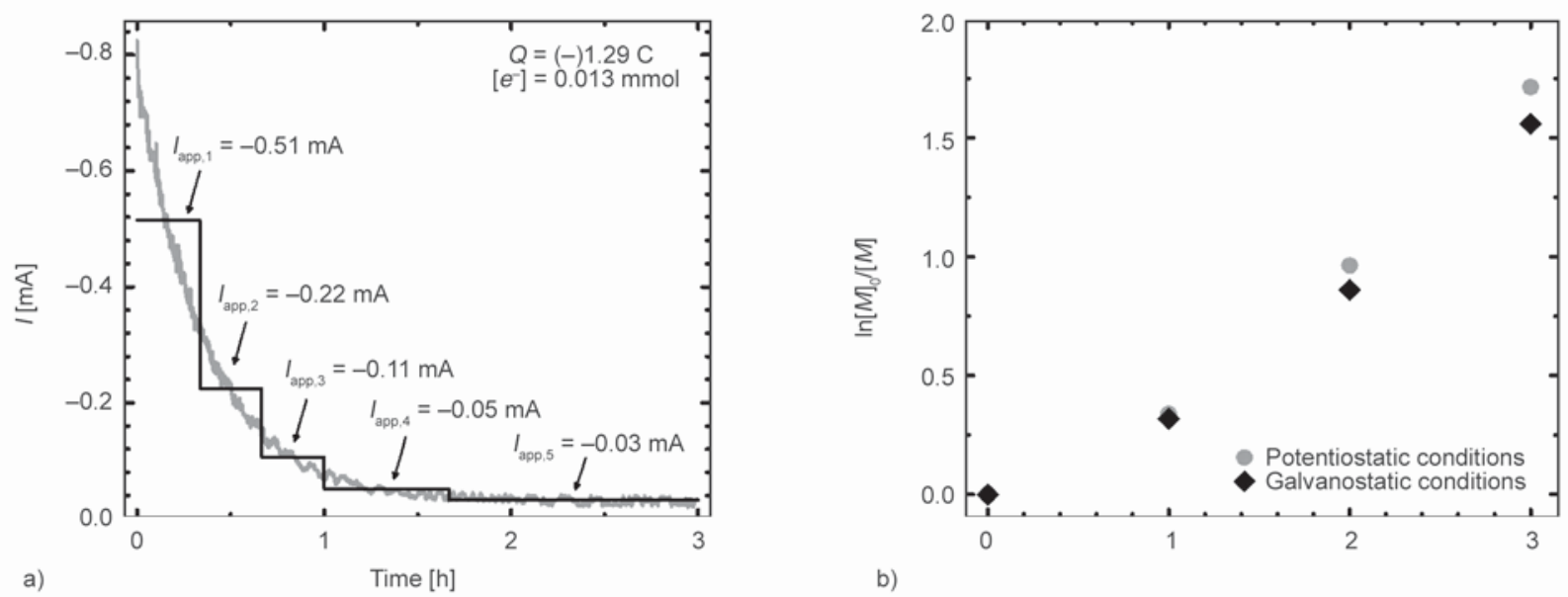

b)

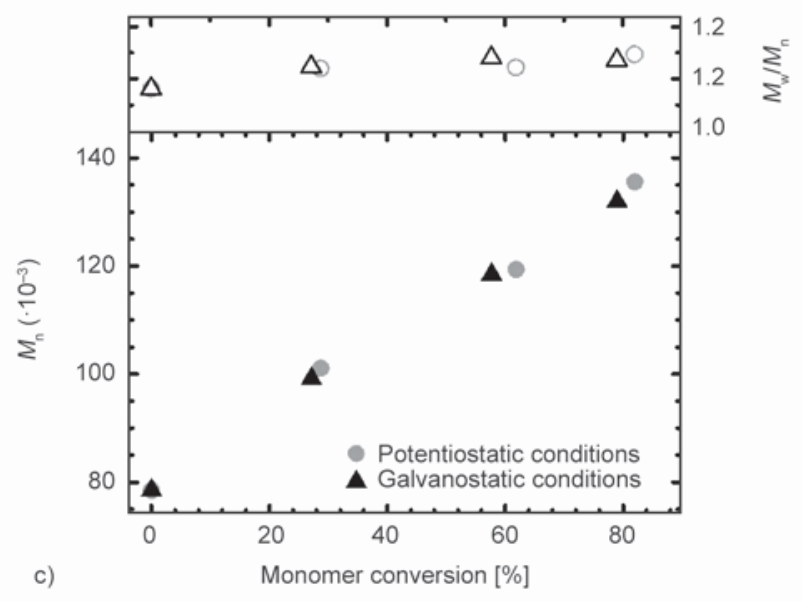

Figure 7. Multi-step preparative electrolysis for seATRP; (a) preparative electrolysis results from applied potential conditions (grey line) and applied current (black line), (b) first-order kinetic plot of monomer conversion versus time, and (c) $M_{\mathrm{n}}$ and $M_{\mathrm{w}} / M_{\mathrm{n}}$ versus monomer conversion by potentiostatic and galvanostatic conditions. Reaction conditions: $[\mathrm{BA}]_{0} /\left[\beta-\mathrm{CD}-(\mathrm{PDMAEMA}-\mathrm{Br})_{21}(\mathrm{per}-\mathrm{Br})\right]_{0} /\left[\mathrm{Cu}^{\mathrm{II}} \mathrm{Br}_{2} / 2 \mathrm{TPMA}\right]_{0}=32 / 1 / 0.0013,[\mathrm{BA}]_{0}=2.1 \mathrm{M},\left[\mathrm{Cu}^{\mathrm{II}} \mathrm{Br}_{2} / 2 \mathrm{TPMA}_{0}=\right.$ $0.08 \mathrm{mM}, T=50^{\circ} \mathrm{C},[\mathrm{TBAP}]_{0}=0.2 \mathrm{M}, V_{\mathrm{tot}}=16 \mathrm{~mL}$.

Close to identical first-order kinetic plots were observed (Figure 7b), and DP of resulting copolymers increased linearly with monomer conversion (Figure 7c) indicating high initiation efficiency. The differences between theoretical and measured MW originate the differences in hydrodynamic radius of star and linear polymer standards for GPC. Moreover, GPC analysis indicated narrow MWD (Figure 7c and $8 \mathrm{a}-\mathrm{b})$ confirming that the halogen end groups were preserved during the seATRP of BA. In this case the $\%$ of chains terminated by radical means are below $1 \%$, what indicating that seATRP was conducted 

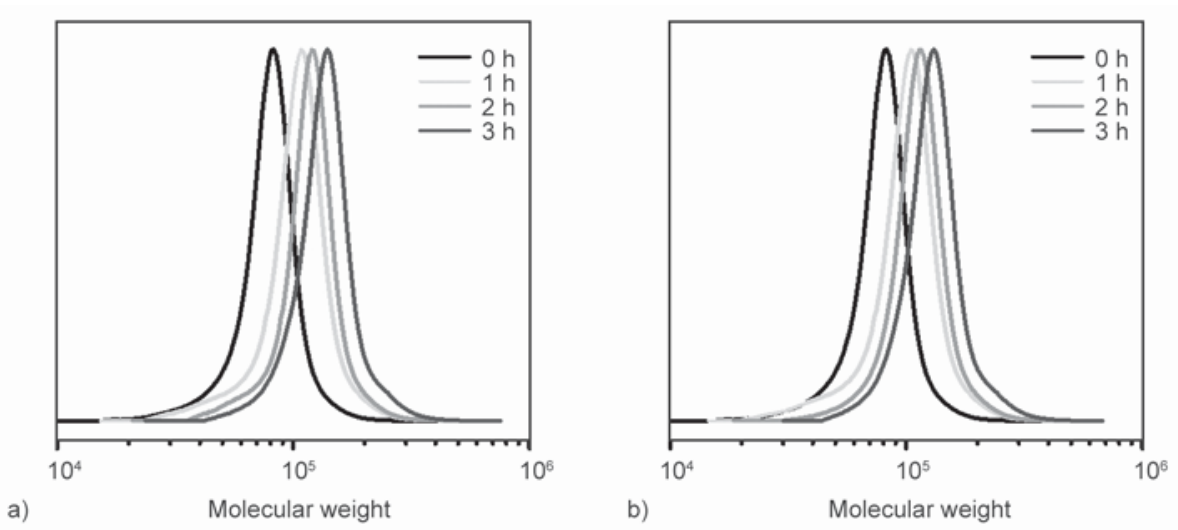

Figure 8. GPC traces of BA polymerization in the presence of $\beta-\mathrm{CD}-(\mathrm{PDMAEMA}-\mathrm{Br})_{21}$ under different conditions: potentiostatic seATRP (a) and galvanostatic seATRP (b)

with preserved chain end functionality, therefore the bimodality cannot be detected by GPC, even if termination will be $100 \%$ of coupling. Probability of the intramolecular termination of acrylates can be enhanced due to a close proximity of radicals but also can be diminished due to radical segregation $[15,64]$.

\subsection{Chemical structure of the 21-arm star polymers}

The chemical structure of the synthesized $\beta$-CD$\left(\text { PDMAEMA }_{28}\right)_{21}$ star polymer (Table 1, entry 5) and $\beta$-CD-(PDMAEMA $\left.28-\mathrm{PBA}_{25}\right)_{21}$ star block copolymer (Table 1, entry 7) were confirmed by ${ }^{1} \mathrm{H}$ NMR spectroscopy (Figure 9 and 10).

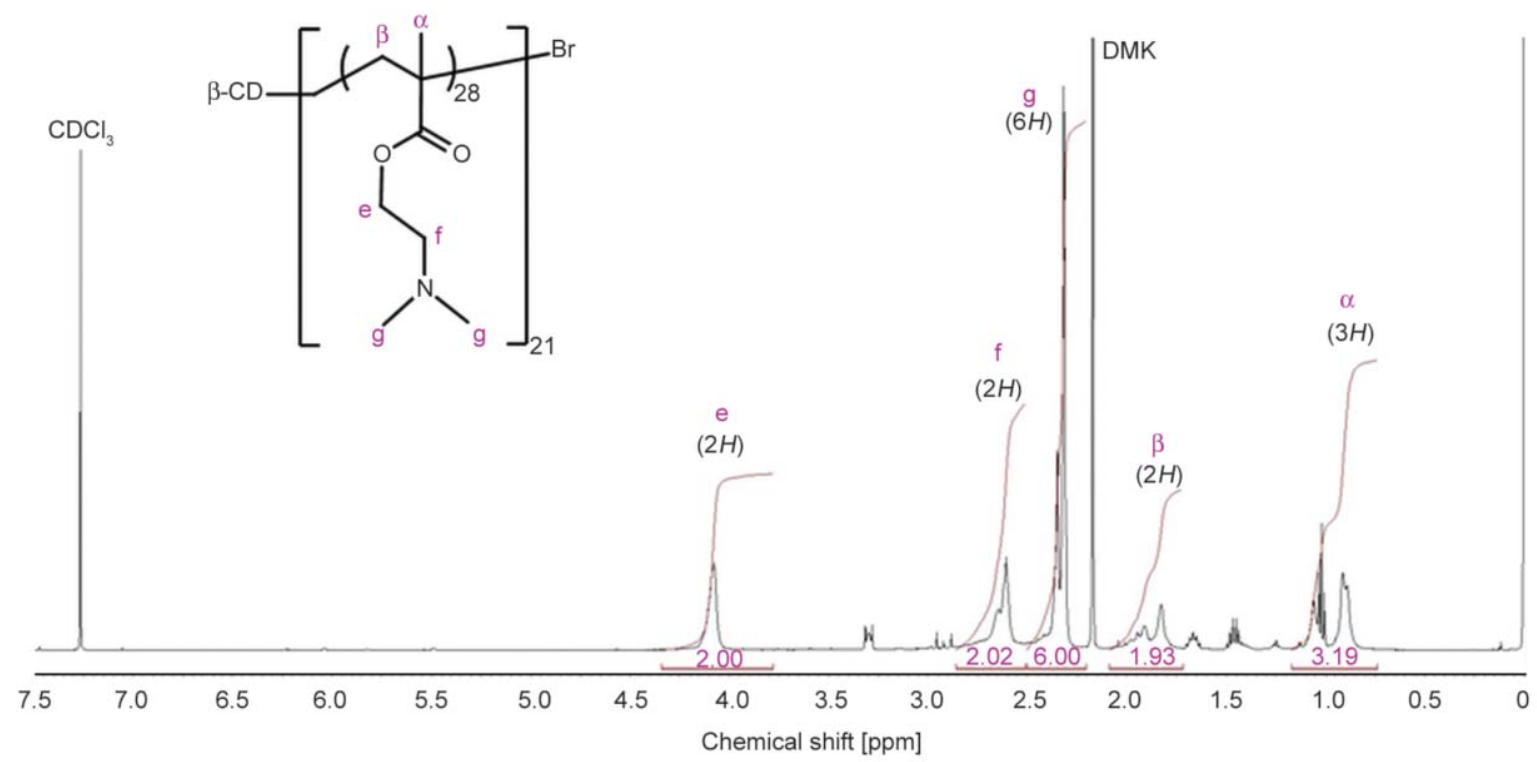

The ${ }^{1} \mathrm{H}$ NMR spectrum shown in Figure 9 confirms the structure of $\beta$-CD-(PDMAEMA 28$)_{21}$ star cationic polymer obtained through seATRP under galvanostatic conditions (Table 1 , entry 5 ). The chemical shifts, $0.75-1.17,1.72-2.09,2.20-2.50,2.51-2.86$, and $3.78-4.34 \mathrm{ppm}$, are mainly attributable to the $-\mathrm{CH}_{3}(\alpha),-\mathrm{CH}_{2}-(\beta),-\mathrm{CH}_{3}(\mathrm{~g}),-\mathrm{CH}_{2}-(\mathrm{f})$, and $-\mathrm{OCH}_{2}-$ (e) groups of the PDMAEMA units in the arms, respectively, indicating the presence of PDMAEMA chains [65]. While, in the ${ }^{1} \mathrm{H}$ NMR spectrum of the star block copolymer (Figure 10), the chemical shifts, $0.75-1.18 \mathrm{~m}, 1.31-2.02,2.18-$ $2.55,2.57-2.86$, and $3.78-4.34 \mathrm{ppm}$, are mainly attributed by the $-\mathrm{CH}_{3}(\mathrm{~d}),-\mathrm{CH}_{2}-\left(\beta^{\prime}+\mathrm{b}+\mathrm{c}\right),-\mathrm{CH}-$ $\left(\alpha^{\prime}\right)$, and $-\mathrm{OCH}_{2}-(\mathrm{a})$ groups of the PBA units in the

Figure 9. ${ }^{1} \mathrm{H}$ NMR spectrum of $\mathrm{CD}$ star homopolymers with PDMAEMA arms $\left(\beta-\mathrm{CD}-(\mathrm{PDMAEMA} 28)_{21}\right.$; Table 1 , entry 5; $\left.M_{\mathrm{n}}=97100, Ð=1.08\right)$ after purification (in $\mathrm{CDCl}_{3}$ ) 


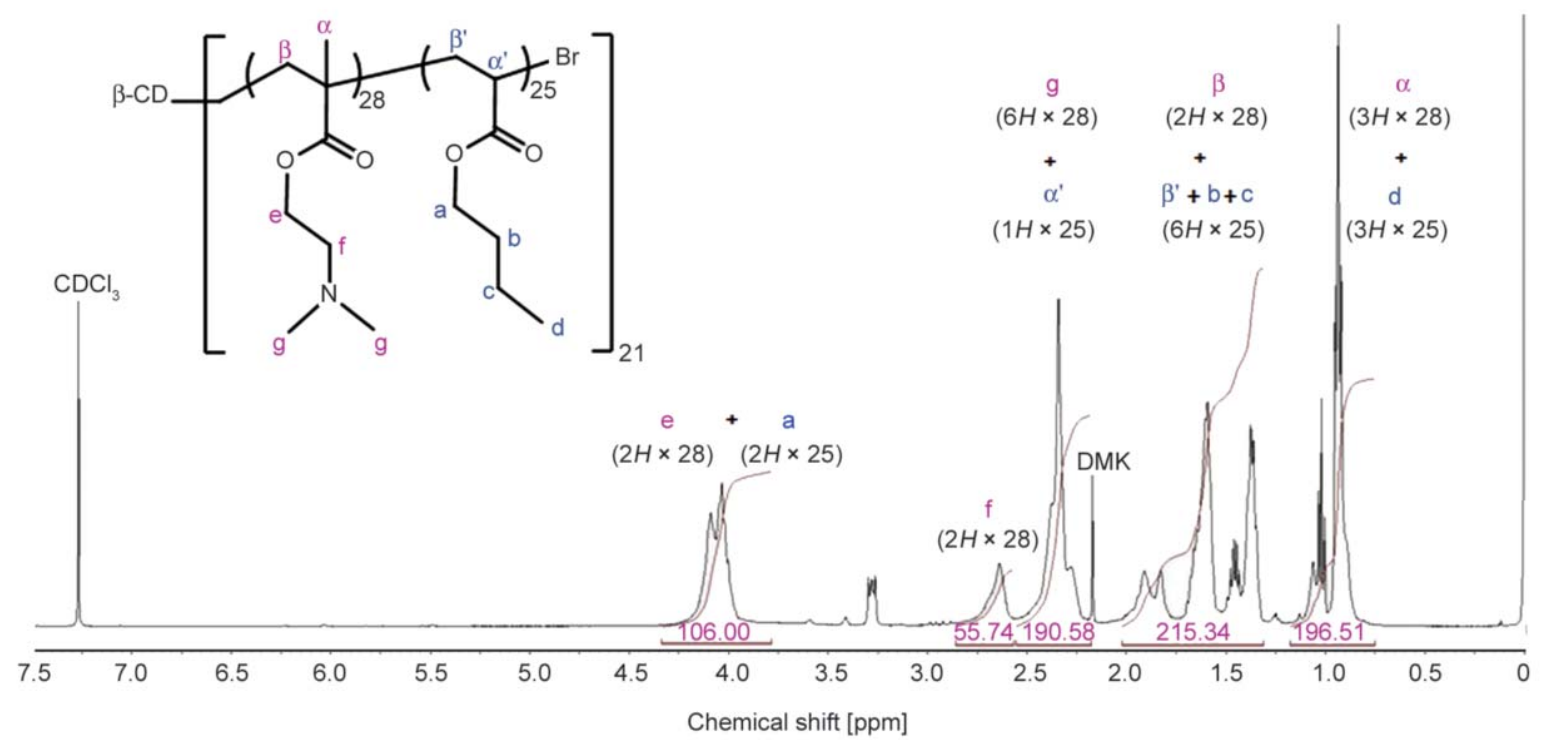

Figure 10. ${ }^{1} \mathrm{H}$ NMR spectrum of star block copolymer $\left(\beta-\mathrm{CD}-\left(\mathrm{PDMAEMA}_{28}-\mathrm{PBA}_{25}\right)_{21}\right.$; Table 1 , entry $7 ; M_{\mathrm{n}}=165100, Ð=$ 1.14) after purification (in $\mathrm{CDCl}_{3}$ )

arms, respectively, indicating the presence of PBA chains [15].

\section{Conclusions}

The controlled 21-arm star polymers consisting of a $\beta$-CD core and PDMAEMA arms were successfully prepared via simplified electrochemically mediated atom transfer radical polymerization with low concentrations of catalyst ( $40 \mathrm{ppm}$ of $\mathrm{Cu}^{\mathrm{II}}$ species). The rate of the polymerizations was controlled by applying less negative $E_{\text {app }}$ and therefore eliminating intermolecular termination reactions between growing arms. Chain extension of the initially formed hydrophilic star polymer with a more hydrophobic monomer (BA), confirmed the preservation of terminal halogen end group during the seATRP of methacrylates. The use of a galvanostatic technique provided similar results to polymerizations conducted under potentiostatic conditions, providing polymers with molecular weight evolution close to theoretical values, while generating stars with narrow molecular weight distribution. Furthermore, the results from ${ }^{1} \mathrm{H}$ NMR spectral studies support the formation of star block (co)polymers. These new amphiphilic polyelectrolyte star copolymers are promising candidates for potential applications in biomedical fields, such as drug delivery, gene delivery, and antifouling coatings.

\section{Acknowledgements}

Financial support from U-553/DS is gratefully acknowledged. NMR spectra were recorded in the Laboratory of Spectrometry, Faculty of Chemistry, Rzeszow University of Technology and were financed from DS budget.

\section{References}

[1] Wang J-S., Matyjaszewski K.: Controlled/'living' radical polymerization. Atom transfer radical polymerization in the presence of transition-metal complexes. Journal of the American Chemical Society, 117, 5614-5615 (1995).

DOI: $10.1021 / \mathrm{ja} 00125 \mathrm{a} 035$

[2] Matyjaszewski K., Jo S. M., Paik H-J., Shipp D. A.: An investigation into the $\mathrm{CuX} / 2,2^{\prime}$-bipyridine $(\mathrm{X}=\mathrm{Br}$ or $\mathrm{Cl}$ ) mediated atom transfer radical polymerization of acrylonitrile. Macromolecules, 32, 6431-6438 (1999). DOI: $10.1021 / \mathrm{ma} 9905526$

[3] Ishizu K., Satoh J., Sogabe A.: Architecture and solution properties of AB-type brush-block-brush amphiphilic copolymers via ATRP techniques. Journal of Colloid and Interface Science, 274, 472-479 (2004). DOI: $10.1016 /$ j.jcis.2004.03.044

[4] Ayres N.: Atom transfer radical polymerization: A robust and versatile route for polymer synthesis. Polymer Reviews, 51, 138-162 (2011). DOI: $10.1080 / 15583724.2011 .566402$

[5] Matyjaszewski K.: Atom transfer radical polymerization (ATRP): Current status and future perspectives. Macromolecules, 45, 4015-4039 (2012).

DOI: $10.1021 / \mathrm{ma} 3001719$ 
[6] He W., Jiang H., Zhang L., Cheng Z., Zhu X.: Atom transfer radical polymerization of hydrophilic monomers and its applications. Polymer Chemistry, 4, 2919-2938 (2013). DOI: $10.1039 / \mathrm{C} 3 \mathrm{PY} 00122 \mathrm{~A}$

[7] Ran J., Wu L., Zhang Z., Xu T.: Atom transfer radical polymerization (ATRP): A versatile and forceful tool for functional membranes. Progress in Polymer Science, 39, 124-144 (2014).

DOI: $10.1016 /$ j.progpolymsci.2013.09.001

[8] Pangilinan K., Advincula R.: Cyclic polymers and catenanes by atom transfer radical polymerization (ATRP). Polymer International, 63, 803-813 (2014).

DOI: $10.1002 /$ pi.4717

[9] Joubert F., Musa O. M., Hodgson D. R. W., Cameron N. R.: The preparation of graft copolymers of cellulose and cellulose derivatives using ATRP under homogeneous reaction conditions. Chemical Society Reviews, 43, 7217-7235 (2014).

DOI: $10.1039 / C 4 C S 00053 F$

[10] Hadasha W., Klumperman B.: Atom transfer radical polymerization as a powerful tool in the synthesis of molecular brushes. Polymer International, 63, 824-834 (2014).

DOI: $10.1002 /$ pi.4697

[11] Król P., Chmielarz P.: Recent advances in ATRP methods in relation to the synthesis of copolymer coating materials. Progress in Organic Coatings, 77, 913-948 (2014).

DOI: $10.1016 /$ j.porgcoat.2014.01.027

[12] Ding M., Jiang X., Zhang L., Cheng Z., Zhu X.: Recent progress on transition metal catalyst separation and recycling in ATRP. Macromolecular Rapid Communications, 36, 1702-1721 (2015).

DOI: $10.1002 /$ marc. 201500085

[13] Rwei S-P., Shu K-T., Way T-F., Chang S-M., Chiang W-Y., Pan W-C.: Synthesis and characterization of hyperbranched copolymers hyper- $g$-(NIPAAm-co-IAM) via ATRP. Colloid and Polymer Science, 294, 291-301 (2015).

DOI: $10.1007 / \mathrm{s} 00396-015-3775-5$

[14] Park S., Chmielarz P., Gennaro A., Matyjaszewski K.: Simplified electrochemically mediated atom transfer radical polymerization using a sacrificial anode. Angewandte Chemie International Edition, 54, 2388-2392 (2015).

DOI: 10.1002/anie.201410598

[15] Chmielarz P., Park S., Sobkowiak A., Matyjaszewski K.: Synthesis of $\beta$-cyclodextrin-based star polymers via a simplified electrochemically mediated ATRP. Polymer, 88, 36-42 (2016).

DOI: $10.1016 /$ j.polymer.2016.02.021

[16] Bortolamei N., Isse A. A., Magenau A. J. D., Gennaro A., Matyjaszewski K.: Controlled aqueous atom transfer radical polymerization with electrochemical generation of the active catalyst. Angewandte Chemie International Edition, 50, 11391-11394 (2011).

DOI: $\underline{10.1002 / \text { anie. } 201105317}$
[17] Chmielarz P., Park S., Simakova A., Matyjaszewski K.: Electrochemically mediated ATRP of acrylamides in water. Polymer, 60, 302-307 (2015). DOI: $10.1016 /$ j.polymer.2015.01.051

[18] Chmielarz P., Krys P., Park S., Matyjaszewski K.: PEO$b$-PNIPAM copolymers via SARA ATRP and eATRP in aqueous media. Polymer, 71, 143-147 (2015). DOI: $10.1016 /$ j.polymer.2015.06.042

[19] Magenau A. J. D., Bortolamei N., Frick E., Park S., Gennaro A., Matyjaszewski K.: Investigation of electrochemically mediated atom transfer radical polymerization. Macromolecules, 46, 4346-4353 (2013). DOI: 10.1021/ma400869e

[20] Magenau A. J. D., Strandwitz N. C., Gennaro A., Matyjaszewski K.: Electrochemically mediated atom transfer radical polymerization. Science, 332, 81-84 (2011). DOI: $10.1126 /$ science.1202357

[21] Li B., Yu B., Huck W. T. S., Zhou F., Liu W.: Electrochemically induced surface-initiated atom-transfer radical polymerization. Angewandte Chemie International Edition, 124, 5182-5185 (2012). DOI: 10.1002/anie.201201533

[22] Li B., Yu B., Huck W. T. S., Liu W., Zhou F.: Electrochemically mediated atom transfer radical polymerization on nonconducting substrates: Controlled brush growth through catalyst diffusion. Journal of the American Chemical Society, 135, 1708-1710 (2013). DOI: 10.1021/ja3116197

[23] Park S., Cho H. Y., Wegner K. B., Burdynska J., Magenau A. J. D., Paik H-J., Jurga S., Matyjaszewski K.: Star synthesis using macroinitiators via electrochemically mediated atom transfer radical polymerization. Macromolecules, 46, 5856-5860 (2013).

DOI: $10.1021 / \mathrm{ma} 401308 \mathrm{e}$

[24] Chmielarz P., Sobkowiak A., Matyjaszewski K.: A simplified electrochemically mediated ATRP synthesis of PEO-b-PMMA copolymers. Polymer, 77, 266-271 (2015). DOI: $10.1016 /$ j.polymer.2015.09.038

[25] Shida N., Koizumi Y., Nishiyama H., Tomita I., Inagi S.: Electrochemically mediated atom transfer radical polymerization from a substrate surface manipulated by bipolar electrolysis: Fabrication of gradient and patterned polymer brushes. Angewandte Chemie International Edition, 54, 3922-3926 (2015). DOI: 10.1002 /ange.201412391

[26] Guo J-K., Zhou Y-N., Luo Z-H.: Kinetic insight into electrochemically mediated ATRP gained through modeling. AIChE Journal, 61, 4347-4357 (2015).

DOI: $10.1002 /$ aic. 14969

[27] Hosseiny S. S., van Rijn P.: Surface initiated polymerizations via e-ATRP in pure water. Polymers, 5, 12291240 (2013).

DOI: $10.3390 /$ polym5041229 
[28] Fantin M., Isse A. A., Gennaro A., Matyjaszewski K.: Understanding the fundamentals of aqueous ATRP and defining conditions for better control. Macromolecules, 48, 6862-6875 (2015). DOI: $10.1021 /$ acs.macromol.5b01454

[29] Sun Y., Du H., Deng Y., Lan Y., Feng C.: Preparation of polyacrylamide via surface-initiated electrochemical-mediated atom transfer radical polymerization (SIeATRP) for $\mathrm{Pb}^{2+}$ sensing. Journal of Solid State Electrochemistry, 20, 105-113 (2016). DOI: $10.1007 / \mathrm{s} 10008-015-3008-3$

[30] Strover L. T., Malmström J., Stubbing L. A., Brimble M. A., Travas-Sejdic J.: Electrochemically-controlled grafting of hydrophilic brushes from conducting polymer substrates. Electrochimica Acta, 188, 57-70 (2016). DOI: 10.1016/j.electacta.2015.11.106

[31] Sun Y., Du H., Lan Y., Wang W., Liang Y., Feng C., Yang M.: Preparation of hemoglobin $(\mathrm{Hb})$ imprinted polymer by $\mathrm{Hb}$ catalyzed eATRP and its application in biosensor. Biosensors and Bioelectronics, 77, 894-900 (2016). DOI: $\underline{\text { 10.1016/j.bios.2015.10.067 }}$

[32] Li J., Xiao H., Kim Y. S., Lowe T. L.: Synthesis of watersoluble cationic polymers with star-like structure based on cyclodextrin core via ATRP. Journal of Polymer Science Part A: Polymer Chemistry, 43, 6345-6354 (2005). DOI: $10.1002 /$ pola.21058

[33] Georgiou T. K., Vamvakaki M., Phylactou L. A., Patrickios C. S.: Synthesis, characterization, and evaluation as transfection reagents of double-hydrophilic star copolymers: Effect of star architecture. Biomacromolecules, 6, 2990-2997 (2005).

DOI: $10.1021 / \mathrm{bm} 050307 \mathrm{w}$

[34] Xu F. J., Zhang Z. X., Ping Y., Li J., Kang E. T., Neoh K. G.: Star-shaped cationic polymers by atom transfer radical polymerization from $\beta$-cyclodextrin cores for nonviral gene delivery. Biomacromolecules, 10, 285 293 (2009).

DOI: $10.1021 / \mathrm{bm} 8010165$

[35] Li J., Guo Z., Xin J., Zhao G., Xiao H.: 21-arm star polymers with different cationic groups based on cyclodextrin core for DNA delivery. Carbohydrate Polymers, 79, 277-283 (2010).

DOI: $10.1016 /$ j.carbpol.2009.08.006

[36] Wu Y., Ni P., Zhang M., Zhu X.: Fabrication of microgels via supramolecular assembly of cyclodextrin-containing star polycations and oppositely charged linear polyanions. Soft Matter, 6, 3751-3758 (2010).

DOI: $10.1039 / C 000979 B$

[37] Xiu K. M., Yang J. J., Zhao N. N., Li J. S., Xu F. J.: Multiarm cationic star polymers by atom transfer radical polymerization from $\beta$-cyclodextrin cores: Influence of arm number and length on gene delivery. Acta Biomaterialia, 9, 4726-4733 (2013).

DOI: $10.1016 /$ j.actbio.2012.08.020
[38] Durmaz Y. Y., Lin Y-L., ElSayed M. E. H.: Development of degradable, $\mathrm{pH}$-sensitive star vectors for enhancing the cytoplasmic delivery of nucleic acids. Advanced Functional Materials, 23, 3885-3895 (2013). DOI: $10.1002 / \mathrm{adfm} .201203762$

[39] Li S., Xiao M., Zheng A., Xiao H.: Synthesis and characterization of a novel water-soluble cationic diblock copolymer with star conformation by ATRP. Materials Science and Engineering: C, 43, 350-358 (2014). DOI: $10.1016 / \mathrm{j} . \mathrm{msec} .2014 .06 .031$

[40] Wang L., Yang Y-W., Zhu M., Qiu G., Wu G., Gao H.: $\beta$ cyclodextrin-conjugated amino poly(glycerol methacrylate)s for efficient insulin delivery. RSC Advances, 4, 6478-6485 (2014). DOI: 10.1039/C3RA47150K

[41] Pan Y., Xue Y., Snow J., Xiao H.: Tailor-made antimicrobial/antiviral star polymer via ATRP of cyclodextrin and guanidine-based macromonomer. Macromolecular Chemistry and Physics, 216, 511-518 (2015).

DOI: $10.1002 / \mathrm{macp} .201400525$

[42] Zhang M., Shen W., Xiong Q., Wang H., Zhou Z., Chen W., Zhang Q.: Thermo-responsiveness and biocompatibility of star-shaped poly[2-(dimethylamino)ethyl methacrylate]- $b$-poly(sulfobetaine methacrylate) grafted on a $\beta$-cyclodextrin core e. RSC Advances, 5, 2813328140 (2015).

DOI: $10.1039 / C 5 R A 02115 \mathrm{D}$

[43] Loh X. J., Wu Y-L.: Cationic star copolymers based on $\beta$-cyclodextrins for efficient gene delivery to mouse embryonic stem cell colonies. Chemical Communications, 51, 10815-10818 (2015). DOI: $10.1039 / \mathrm{C} 5 \mathrm{CC} 03686 \mathrm{~K}$

[44] Jiang X., Wu J., Zhang L., Cheng Z., Zhu X.: A facile strategy for catalyst separation and recycling suitable for ATRP of hydrophilic monomers using a macroligand. Macromolecular Rapid Communications, 37, 143-148 (2016).

DOI: $10.1002 /$ marc.201500439

[45] Plamper F. A., Ruppel M., Schmalz A., Borisov O., Ballauff M., Müller A. H. E.: Tuning the thermoresponsive properties of weak polyelectrolytes: Aqueous solutions of star-shaped and linear poly $(N, N$-dimethylaminoethyl methacrylate). Macromolecules, 40, 8361-8366 (2007). DOI: $\underline{10.1021 / \mathrm{ma} 071203 \mathrm{~b}}$

[46] Yancheva E., Paneva D., Maximova V., Mespouille L., Dubois P., Manolova N., Rashkov I.: Polyelectrolyte complexes between (cross-linked) $\mathrm{N}$-carboxyethylchitosan and (quaternized) poly[2-(dimethylamino)ethyl methacrylate]: Preparation, characterization, and antibacterial properties. Biomacromolecules, 8, 976-984 (2007). DOI: $10.1021 / \mathrm{bm} 061029 \mathrm{j}$

[47] Plamper F. A., McKee J. R., Laukkanen A., Nykänen A., Walther A., Ruokolainen J., Aseyev V., Tenhun H.: Miktoarm stars of poly(ethylene oxide) and poly(dimethylaminoethyl methacrylate): Manipulation of micellization by temperature and light. Soft Matter, 5, 18121821 (2009).

DOI: $10.1039 / \mathrm{B} 822143 \mathrm{~J}$ 
[48] Rezaei S. J. T., Nabid M. R., Niknejad H., Entezami A. A.: Folate-decorated thermoresponsive micelles based on star-shaped amphiphilic block copolymers for efficient intracellular release of anticancer drugs. International Journal of Pharmaceutics, 437, 70-79 (2012). DOI: $10.1016 /$ j.ijpharm.2012.07.069

[49] Loh X. J.: Poly(DMAEMA-co-PPGMA): Dual-responsive 'reversible' micelles. Journal of Applied Polymer Science, 127, 992-1000 (2013).

DOI: $10.1002 / a p p .37530$

[50] Loh X. J., Ong S. J., Tung Y. T., Choo H. T.: Co-delivery of drug and DNA from cationic dual-responsive micelles derived from poly(DMAEMA-co-PPGMA). Materials Science and Engineering: C, 33, 4545-4550 (2013).

DOI: $10.1016 /$ j.msec.2013.07.011

[51] Matyjaszewski K., Nakagawa Y., Jasieczek C. B.: Polymerization of $n$-butyl acrylate by atom transfer radical polymerization. Remarkable effect of ethylene carbonate and other solvents. Macromolecules, 31, 1535-1541 (1998). DOI: $10.1021 / \mathrm{ma971444r}$

[52] Zhang H., van der Linde R.: Atom transfer radical polymerization of $n$-butyl acrylate catalyzed by $\mathrm{CuBr} / N-(n-$ hexyl)-2-pyridylmethanimine. Journal of Polymer Science Part A: Polymer Chemistry, 40, 3549-3561 (2002). DOI: $10.1002 /$ pola. 10460

[53] Xia J., Matyjaszewski K.: Controlled/‘living’ radical polymerization. Atom transfer radical polymerization catalyzed by copper(I) and picolylamine complexes. Macromolecules, 32, 2434-2437 (1999). DOI: $10.1021 / \mathrm{ma981694n}$

[54] Li J., Xiao H.: An efficient synthetic-route to prepare [2,3,6-tri-O-(2-bromo-2-methylpropionyl]- $\beta$-cyclodextrin). Tetrahedron Letters, 46, 2227-2229 (2005). DOI: $10.1016 /$ j.tetlet.2005.02.027

[55] Matyjaszewski K., Shipp D. A., Wang J-L., Grimaud T., Patten T. E.: Utilizing halide exchange to improve control of atom transfer radical polymerization. Macromolecules, 31, 6836-6840 (1998).

DOI: $10.1021 / \mathrm{ma9} 90476 \mathrm{r}$

[56] Peng C-H., Kong J., Seeliger F., Matyjaszewski K.: Mechanism of halogen exchange in ATRP. Macromolecules, 44, 7546-7557 (2011).

DOI: $10.1021 / \mathrm{ma} 201035 \mathrm{u}$
[57] Shipp D. A., Wang J-L., Matyjaszewski K.: Synthesis of acrylate and methacrylate block copolymers using atom transfer radical polymerization. Macromolecules, 31, 8005-8008 (1988).

DOI: $10.1021 / \mathrm{ma} 981033 \mathrm{q}$

[58] Dufour B., Koynov K., Pakula T., Matyjaszewski K.: PBA-PMMA 3-arm star block copolymer thermoplastic elastomers. Macromolecular Chemistry and Physics, 209, 1686-1693 (2008).

DOI: $10.1002 / \mathrm{macp} .200800151$

[59] Matyjaszewski K., Tsarevsky N. V.: Macromolecular engineering by atom transfer radical polymerization. Journal of the American Chemical Society, 136, 65136533 (2014). DOI: $10.1021 / \mathrm{ja} 408069 \mathrm{v}$

[60] Matyjaszewski K., Bortolamei N., Magenau A., Gennaro A., Isse A. A.: Electrochemically mediated atom transfer radical polymerization. U.S. Patent 20140183055 A1, USA (2014).

[61] Tang W., Nanda A. K., Matyjaszewski K.: Effect of [pyridylmethanimine] $/\left[\mathrm{Cu}^{\mathrm{I}}\right]$ ratio, ligand, solvent and temperature on the activation rate constants in atom transfer radical polymerization. Macromolecular Chemistry and Physics, 206, 1171-1177 (2005).

DOI: $10.1002 / \mathrm{macp} .200500058$

[62] Seeliger F., Matyjaszewski K.: Temperature effect on activation rate constants in ATRP: New mechanistic insights into the activation process. Macromolecules, 42, 6050-6055 (2009).

DOI: $10.1021 / \mathrm{ma} 9010507$

[63] Cheng G., Böker A., Zhang M., Krausch G., Müller A. H. E.: Amphiphilic cylindrical core-shell brushes via a 'grafting from' process using ATRP. Macromolecules, 34, 6883-6888 (2001). DOI: $10.1021 / \mathrm{ma} 0013962$

[64] Nakamura Y., Lee R., Coote M. L., Yamago S.: Termination mechanism of the radical polymerization of acrylates. Macromolecular Rapid Communications, 37, 506513 (2016). DOI: $10.1002 /$ marc. 201500677

[65] Sevimli S., Sagnella S., Kavallaris M., Bulmus V., Davis T. P.: Synthesis, self-assembly and stimuli responsive properties of cholesterol conjugated polymers. Polymer Chemistry, 3, 2057-2069 (2012).

DOI: 10.1039/C2PY20112G 